\title{
INTERCONNECTION OF SOME INDICATORS OF THE IMMUNE SYSTEM AND THYROID STATUS OF INDIVIDUALS FROM CONTAMINATED AREAS OF SUMY REGION
}

\author{
Bilokur D. O., Sheiko V. H.
}

\section{INTRODUCTION}

It's acknowledged one of the biggest tragedies of $20^{\text {th }}$ century by its consequences is the Chernobyl disaster ${ }^{1}$. Although from the moment of the disaster has passed 33 years, this period of time exceeds the half-life period of 137 Cs. Its activity has been a framework for providing the status of the enhanced radioecological monitoring to an area ${ }^{2}$. The statistics of medical institutions in Sumy region indicates the tendency to overall growth incidence of residents in the region. According to the Annual Public Health Report, the effect of radiological and non-radiological factors that appeared as a result of Chernobyl disaster led to health deterioration of all the categories of population: irradiated people, adult population of radiologically contaminated areas, children etc ${ }^{3}$.

According to the scientific research, Sumy region is the territory of enhanced radioecological monitoring including Shostka and Yampil districts (IV-radiation zone; soil contamination density with cesium isotopes-137 $3,7 \times 10^{4}-18,5 \times 10^{4} \mathrm{~Bq} / \mathrm{m}^{2}$ ), are distinguished by the incidence prevalence for children on tumor ${ }^{4}$. Currently, Sumy region occupies the $21^{\text {st }}$ place (out of 25) based on the incidence of certain classes of diseases. This fact can be explained by the remoteness of the territory of the region from the epicenter of a nuclear explosion and the disfigurement of the soil activity of radionuclides. The health condition issue of adult population who lives in contaminated area is quite controversial.

\footnotetext{
1 Тридцять років Чорнобильської катастрофи: радіологічні та медичні наслідки : національна доповідь України / Д. Базика та ін. Київ: ДУ «Національний науковий центр радіаційної медицини Національної академії медичних наук України», 2016. 177 с.

2 Про організацію виконання постанов Верховної Ради Української РСР про порядок введення в дію законів Української РСР «Про правовий режим території, що зазнала радіоактивного забруднення внаслідок Чорнобильської катастрофи» та «Про статус i соціальний захист громадян, які постраждали внаслідок чорнобильської катастрофи» : постанова Кабінету Міністрів України від 23 липня 1991 р. № 106.

'Щорічна доповідь про стан здоров'я населення, санітарно-епідемічну ситуацію та результати діяльності системи охорони здоров'я України. 2017 р. / МО3 України. ДУ «УІСД МОЗ України». Київ : МВЦ «Медінформ», 2018. 458 с.

4 Динаміка змін у поширеності хвороб та захворюваності дитячого населення раїни за окремими класами хвороб після аварії на Чорнобильській AEC / О. Волосовець та ін. Світ медицини та біології. 2018. № 3 (65). С. 33-42. DOI: 10.26724/2079-8334-2018-3-65-33-42.
} 
It is widely-known that ionizing radiation is an immunosuppressant which has been implemented at the level of the genetic apparatus and biological membranes of immune cells. According to modern opinions, the radiation-induced destabilization of the human genome is potentially oncogenic ${ }^{5}$. In addition, ionizing radiation is considered to be a powerful stress factor that could potentially lead to a decrease of the immunological status of irradiated individuals.

From scientific sources it is known that residents of the contaminated areas experience prolonged low-intensity irradiation through the soil activity of the $137 \mathrm{Cs}$ isotope, radionuclides get through the respiratory tract and food $^{6 ; 7}$.

With additional exogenous effects of a stress character, the risk of immune system impairment increases ${ }^{8}$. Its activity is integrative and any disruption into links of immunity may affect the system as a whole ${ }^{9 ; 10 ; 11}$. Low-intensity prolonged radiation exposure can have an immunosuppressive effect on specific and non-specific factors and mechanisms of systemic immunity that directly affect the maintenance of the human body homeostasis $^{12 ; 13 ; 14 ; 15 ; 16 .}$

${ }_{6}^{5}$ Ярилин А. Иммунология. Москва : GEOTAR-Media, 2010. 752 c.

${ }^{6}$ Risk of thyroid cancer in the Bryansk Oblast of the Russian Federation after the Chernobyl Power Station accident / S. Davis et al. Radiation Research. 2004. № 162 (3). P. 241-248. DOI: 10.1667/rr3233.

Eheman C., Garbe P., Tuttle R. Autoimmune thyroid disease associated with environmental thyroidal irradiation. Thyroid. 2003. № 13 (5). P. 453-464. DOI: $10.1089 / 105072503322021115$.

Gleeson M. Immune function in sport and exercise. Journal of Applied Physiology. 2007. № 103(2). P. 693-699. DOI: 10.1152/japplphysiol.00008.2007.

Individual differences in cellular immune response to stress / S. Manuck et al. Psychological Science. 1991. № 2 (2). P. 111-115. DOI: $10.1111 / \mathrm{j} .1467-$ 9280.1991.tb00110.x.

10 Effect of ionizing radiation on development process of T-cell population lymphocytes in Chernobyl children / M. Sheikh Sajjadieh et al. Iranian Journal of Radiation Research. 2009. № 7 (3). P. 127-133. URL: Magiran.com/p731386.

${ }_{11}$ The effect of ionizing radiation on the homeostasis and functional integrity of murine splenic regulatory T cells / A. Balogh et al. Inflammation Research. 2013. № 62 (2). P. 201-212. DOI: 10.1007/s00011-012-0567-y.

Kusunoki Y., Hayashi T. Long-lasting alterations of the immune system by ionizing radiation exposure: Implications for disease development among atomic bomb survivors. International Journal of Radiation Biology. 2008. № 84(1). P. 1-14. DOI: 10.1080/09553000701616106.

${ }_{13}$ T-cell immunosenescence and inflammatory response in atomic bomb survivors / Y. Kusunoki et al. Radiation Research. 2010. № 174 (6b). P. 870-876. DOI: 10.1667/RR1847.1.

${ }^{14}$ High mobility group box-1 promotes the proliferation and migration of hepatic stellate cells via TLR4-dependent signal pathways of PI3K/Akt and JNK / F. Wang et al. PloS One. 2013. № 8 (5). P. 643-673. DOI: 10.1371/journal.pone.0064373.

${ }_{5}$ Duffner P. Long-term effects of radiation therapy on cognitive and endocrine function in children with leukemia and brain tumors. The Neurologist. 2004. № 10 (6). P. 293-310. DOI: 10.1097/01.nrl.0000144287.35993.96.

${ }_{16}$ Effects of long-term low-level radiation exposure after the Chernobyl catastrophe on immunoglobulins in children residing in contaminated areas : prospective and crosssectional studies / D. McMahon et al. Environmental Health. 2014. № 13 (1). P. 36-50. DOI: $10.1186 / 1476-069 \mathrm{X}-13-36$. 
In particular, this relates to the psycho-emotional load, which is considered to be one of the most common modern immune suppressants and stimulating agents to trigger adaptive reactions in the body ${ }^{17 ; 18 ; 19}$.

Like the immune, thyroid system, one of the most vulnerable to the consequences of the Chernobyl disaster, which is explained by its significant exposure $131-\mathrm{I}^{20}$. Despite the long time that has passed since then, the risk of developing the thyroid gland pathologies is recognized as quite high by both scientists and medical professionals ${ }^{21}$.

Disorders of the lipid profile and neuroendocrine forms of obesity due to peculiarities of endocrine regulation during puberty, are considered to be significant causes of increased incidence of diseases of different etiology in residents of radiation contaminated territories ${ }^{22 ; 23}$.

Recent data indicate the possibility of remote thyroid pathologies as a result of prolonged low-dose irradiation in the absence of direct exposure to radioactive iodine $e^{24 ; 25 ; 26}$. Often they are combined with a state of high anxiety - typical signs of a stressful situation ${ }^{27}$.

In researches of the Ukrainian scientists, typical signs of stress reactions among individuals aged 18-24 years old who lived on the territory of

17 Segerstrom S., Miller G. Psychological stress and the human immune system: A meta-analytic study of 30 years of inquiry. Psychological Bulletin. 2004. № 130 (4). P. 601. DOI: 10.1037/0033-2909.130.4.601.

${ }_{18}$ Viru A., Viru M. Cortisol-essential adaptation hormone in exercise. International Journal of Sports Medicine. 2004. № 25 (6). P. 461-464. DOI: 10.1055/s-2004-821068.

19 Psychophysiological stress in tennis players during the first single match of a tournament / E. Filaire et al. Psychoneuro-endocrinology. 2009. № 34 (1). P. 150-157. DOI: 10.1016/j.psyneuen.2008.08.022.

${ }^{20}$ John D., Boice Jr. Chapter 3 - From Chernobyl to Fukushima and Beyond A focus on thyroid cancer. Thyroid cancer and nuclear accidents. Long-term aftereffects of Chernobyl and Fukushima. 2017. P. 21-32.

${ }^{21}$ Non-cancer atherosclerotic effects associated with environmental and therapeutic radiation doses: The Chernobyl thyroid cancer children study / R. Bruno et al. International Journal of Cardiology. 2013. № 168 (4). P. 4255-4257. DOI: 10.1016/j.ijcard.2013.04.161.

${ }_{22}$ Особливості ліпідного спектра крові у нащадків ліквідаторів аварії на ЧАЕС / М. Коренєв та ін. Современная педиатрия. 2009. № 3. С. 56-58.

23 Рожко А. Чернобыльская катастрофа: медико-биологические закономерности формирования и прогнозирование тиреоидной патологии у населения. Міжнародний ендокринологічний журнал. 2011. № 4. С. 84-93.

${ }^{24}$ Low dose irradiation of thyroid cells reveals a unique transcriptomic and epigenetic signature in RET/PTC-positive cells / K. Abou-El-Ardat et al. Mutation Research / Fundamental and Molecular Mechanisms of Mutagenesis. 2012. № 731 (1). P. 27-40. DOI: $10.1016 /$ j.mrfmmm.2011.10.006.

${ }^{25}$ Fushiki S. Radiation hazards in children-lessons from Chernobyl, Three Mile Island and Fukushima. Brain and Development. 2013. № 35(3), P. 220-227. DOI: 10.1016/j.braindev.2012.09.004.

${ }_{26}$ Radiation and risk of thyroid cancer: Fukushima and Chernobyl / N. Takamura et al. The Lancet Diabetes and Endocrinology. 2016. № 4 (8). P. 647. DOI: 10.1016/S22138587(16)30112-7.

${ }^{27}$ Contis G., Foley Jr. Depression, suicide ideation, and thyroid tumors among Ukrainian adolescents exposed as children to Chernobyl radiation. Journal of clinical medicine research. 2015. № 7 (5). P. 332-338. DOI: 10.14740/jocmr2018w. 
enhanced radiation control were marked, in particular, raised the level of cortisol $^{28}$, which increased further in conditions of additional psycho-

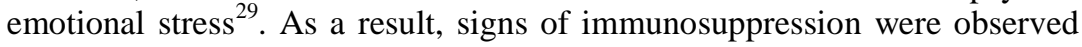
in this group, which were accompanied by an imbalance of thyroid status and lipid metabolism, changes in oxidative and antioxidant activity ${ }^{30 ; 31 ; 32}$. In our previous studies ${ }^{33 ; 34 ; 35}$ the obtained results indicate the functional load of the cellular and humoral parts of systemic immune system among the population of radiation-polluted territories of the Sumy region. At the same time, the formation of compensatory mechanisms in response to lowintensity prolonged radiation irradiation is observed.

Thyroid dysfunction causes a number of health problems, including the development of atherosclerosis; autoimmune and allergic diseases, severe changes all without exception organs and systems, including the mental sphere $^{36 ; 37 ; 38}$.

${ }^{28}$ Соколенко В., Соколенко С. Активність радіонуклідів і реалізація функцій імунної системи у мешканців радіаційно забруднених територій. Вісник Дніпропетровського університету. Серія «Біологія, медицина». 2015. № 6 (2). C. 93-96. DOI: 10.15421/021517.

${ }_{29}$ Соколенко В., Соколенко С. Вплив факторів стресової природи на показники імунної системи. Вісник Черкаського університету. Біологічні науки. 2015. № 19 (352). С. 110-114.

30 Соколенко В.Л. Показники клітинного імунітету в осіб 3 певними особливостями тиреоїдного статусу за умов хронічного опромінення в малих дозах. Вісник проблем біологї̈ і медицини. 2016. № 1 (126). С. 403-409.

${ }^{31}$ Sokolenko V., Sokolenko S. The interaction between lipid exchange and thyroid status in the conditions of prolonged influence of small doses of radiation. Regulatory Mechanisms in Biosystems. 2017. № 8 (2). P. 231-238. DOI: 10.15421/021736.

${ }^{32}$ Interconnection of the immune system and the intensity of the oxidative processes under conditions of prolonged exposure to small doses of radiation / V. Sokolenko et al. Regulatory Mechanisms in Biosystems. 2018. № 9(2). P. 167-176. DOI: $10.15421 / 021825$.

33 Білокур Д. Показники неспецифічного антиінфекційного захисту у осіб 3 територій посиленого радіоекологічного контролю Сумської області. Вісник Східноєвропейського національного університету імені Лесі Украӥнки. Серія «Біологічні науки». 2018. № 4 (377). С. 86-91.

${ }^{34}$ Білокур Д., Львов О., Шейко В. Динаміка показників гуморального імунітету у осіб 3 контамінованих територій Сумської області. Вісник проблем біології $i$ медииини. 2018. № 3 (145). C. 59-62. DOI: 10.29254/2077-4214-2018-3-1-145-59-62.

${ }^{35}$ Білокур Д. Динаміка показників клітинного імунітету у осіб з контамінованих територій Сумської області. Вісник проблем біологї $i$ медицини. 2018. Вип. 4. T. 2 (147). C. 113-116. DOI: 10.29254/2077-4214-2018-4-2-147.

${ }^{36}$ Higher free triiodothyronine is associated with non-alcoholic fatty liver disease in euthyroid subjects: The lifelines cohort study / E. van den Berg et al. Metabolism. 2017. № 67. P. 62-71. DOI: 10.1016/j.metabol.2016.11.002.

37 Hidaka Y. Chronic thyroiditis (Hashimoto's disease). Nippon Rinsho. 2005. № 63 (10). P. 111-115.

38 Establishment of clinical diagnosis model of Graves' disease and Hashimoto's thyroiditis / Z. Cui et al. JTransl. Med. 2019. № 17 (1). P. 11. DOI: 10.1186/s12967-0181765-3. 
However, most of the data on the involvement of cellular and humoral factors of the immune system, the occurrence and formation of autoimmune and allergic conditions are contradictory and incomplete.

So, we think, all the above-mentioned evidences determined the timeliness of our research and defined its goal - to ascertain the interconnection of some indicators of the immune system and thyroid status of individuals from contaminated areas of Sumy region.

\section{Materials and methods of the research}

In 2018 there were examined 30 individuals including the ones from contaminated areas (control group, 20 individuals) and residents from the enhanced radiological monitoring areas (IV-radiation zone; soil contamination density with cesium isotopes-137 $3,7 \times 10^{4}-18,5 \times 10^{4}$ $\mathrm{Bq} / \mathrm{m}^{2}$ ). All the examined individuals were students or staff members of Sumy State Teachers' Training University at the age from 18 to 35 and during the examination they had no acute diseases. Statistically, there were no significant difference between sexes of the examined individuals (women were examined during the follicular phase of menstrual period) that is why they were examined as a unitary group.

The total number of leukocytes was calculated with hemocytometer, absolute and relative quantities of their populations were calculated with help of Romanowski-Giemsa staining. Cell-surface antigene expression with Peripheral Blood Leukocytes was determined by means of immunofluorescence using monoclonal antibody to LT 3 (for testing the expression of Pan-T-cells CD3), LT 4 (for testing the activity expression of T-helper-cells CD4), LT 8 (for testing the expression of CD8), LNK 16 (for testing the expression of CD16). The level of immunoglobulins in serum was determined with the help of radial immunodiffusion technique (Mancini) using monotypic serum against $\operatorname{IgG}(\mathrm{H}), \operatorname{IgM}(\mathrm{H}), \operatorname{IgA}(\mathrm{H})$. The immunoregulatory index was calculated ${ }^{39}$.

Thyrotropic hormone (TTH) content was determined using a RIA-TTH test kit (Immunotech, Czech Republic). The content of thyroxine (T4) in the serum was examined using a test kit of rio-t4-iPr, triiodothyronine (T3) rio-t3-iPr (Institute of Bioorganic Chemistry of the National Academy of Sciences of the Republic of Belarus).

The examinations of the volunteers and their blood sampling were held by the medical staff of the Laboratory and Diagnostic Center "Diagnostyka Zdorov'ya" (Sumy, Ukraine). The blood sampling took place in the morning; all the individuals were in the fasted state. Status data about the radiation contamination was received at sanitary-epidemiological agency (Sumy, Ukraine).

39 Меньшиков В. Лабораторные методы исследования в клинике. Москва : Медицина, 1987. 
The statistical process was performed with help of Microsoft Excel with variuos statistics methods. The authenticity of significance between samples was determined with the Student's T-test. The average values are given as $\mathrm{M} \pm \mathrm{m}$, where $\mathrm{M}$ is arithmetic average and $\mathrm{m}$ is a standard error of the mean. Deviation with $\mathrm{P}<0,05$ was considered as a significant one. Correlation analysis was performed using the Pearson correlation coefficient.

The research was done in compliance with bioethical standards and according to the current legislation of Ukraine ${ }^{40}$. All the volunteers gave the written permission for participation in the examination.

\section{Immune status of individuals from the territories of the intensified radioecological control of Sumy region}

Extreme factors of various kinds affecting the body trigger compensatory-adaptive mechanisms, which accordingly change metabolism and functional state organs and tissues. A single or short-term exposure to these factors, as a rule, does not lead to a stable restructuring of the mechanisms of regulation of homeostasis, where as prolonged and repeated stress can become the basis of stress-induced development of pathology, including the immune system ${ }^{41 ; 42}$.

Systemic immunity indicators of residents from contaminated and conditionally ecologically balanced environment areas of Sumy region that are given in the table, show that over-researched period there is the absolute amount of leukocytes of residents from contaminated areas and has a tendency to decrease.

The absolute amount number of eosinophiles has grown up by 2,67 times and the relative number of eosinophiles has grown up by 2,75 times relative to the values of the control group of which is within the homeostatic norm. Indicators of both groups are within normal.

The absolute and therelative number of basophils level decrease were committed by 2,0 and 1,8 times in the study group and doesn't exceed a clinical standard. Absolute neutrophil level decrease was committed by $12 \%$. At the same time, the decrease of relative number of monocytes by 1,26 times, respectively, reaches reliable values.

During the research process, the total number of lymphocytes in the control and experimental group are within the clinical norm.

\footnotetext{
40 Додатковий протокол до Конвенції про права людини та біомедицину в галузі біомедичних досліджень (ЕTS № 195) / Верховна Рада України.

${ }^{41}$ Larzelere M., Jones G. Stress and health. Primary Care. Clinics in Office Practice. 2008. № 35 (4). P. 839-856. DOI: 10.1016/j.pop.2008.07.011.

42 Кубасов Р. Гормональные изменения в ответ на экстремальные факторы внешней среды. Вестник Российской академии медицинских наук. 2014. № 69 (9-10). С. 102-109.
} 
Table 1

Indicators of systemic immunity of individuals from contaminated and conditionally ecologically balanced environment territories of Sumy region

\begin{tabular}{|c|c|c|c|}
\hline Indicator & $\begin{array}{c}\text { Clinical } \\
\text { norm }\end{array}$ & $\begin{array}{c}\text { Control group } \\
(\mathbf{M} \pm \mathbf{m}), \mathbf{N}=\mathbf{2 0}\end{array}$ & $\begin{array}{c}\text { Experimental group } \\
(\mathbf{M} \pm \mathbf{m}), \mathbf{N}=\mathbf{3 0}\end{array}$ \\
\hline Leukocytes, $10^{\wedge} 9 / 1$ & $4-12$ & $6,13 \pm 0,15$ & $5,99 \pm 0,17$ \\
\hline Eosinophils, $10^{\wedge} 9 / 1$ & $0,02-0,3$ & $0,06 \pm 0,01$ & $0,16 \pm 0,01$ \\
\hline Eosinophils, \% & $0,5-5$ & $1,00 \pm 0,03$ & $2,75 \pm 0,05^{*}$ \\
\hline Basophils, $10^{\wedge} 9 / 1$ & $0,0-0,065$ & $0,03 \pm 0,01$ & $0,015 \pm 0,01$ \\
\hline Basophils, \% & $0-1$ & $0,45 \pm 0,08$ & $0,25 \pm 0,06^{*}$ \\
\hline Neutrophils, $10^{\wedge} 9 / 1$ & $2,0-5,8$ & $3,71 \pm 0,07$ & $3,27 \pm 0,04 *$ \\
\hline Neutrophils, $\%$ & $48-78$ & $60,52 \pm 0,54$ & $54,58 \pm 0,47$ \\
\hline Monocytes, $10^{\wedge} 9 / 1$ & $0,09-0,6$ & $0,45 \pm 0,08$ & $0,35 \pm 0,06$ \\
\hline Monocytes, \% & $3-11$ & $7,34 \pm 0,13$ & $5,83 \pm 0,11 *$ \\
\hline Lymphocytes, $10^{\wedge} 9 / 1$ & $1-5$ & $1,88 \pm 0,15$ & $2,19 \pm 0,19$ \\
\hline Lymphocytes, $\%$ & $20-40$ & $30,67 \pm 0,24$ & $36,50 \pm 0,27 *$ \\
\hline $\mathrm{CD} 3,10^{\wedge} 9 / 1$ & $0,4-3,8$ & $0,96 \pm 0,03$ & $1,15 \pm 0,05$ \\
\hline $\mathrm{CD} 3, \%$ & $50,0-80,0$ & $50,90 \pm 0,26$ & $52,50 \pm 0,34$ \\
\hline CD4, 10^9/1 & $0,2-2,2$ & $0,45 \pm 0,07$ & $0,52 \pm 0,09$ \\
\hline $\mathrm{CD} 4, \%$ & $33,0-46,0$ & $46,87 \pm 0,13$ & $45,08 \pm 0,17$ \\
\hline CD8, $10^{\wedge} 9 / 1$ & $0,1-1,4$ & $0,27 \pm 0,06$ & $0,34 \pm 0,06$ \\
\hline $\mathrm{CD} 8, \%$ & $17,0-30,0$ & $28,10 \pm 0,14$ & $29,92 \pm 0,20$ \\
\hline $\begin{array}{l}\text { Immunoregulatory index } \\
\text { (CD4 / CD8), c.u. }\end{array}$ & $1,4-2,0$ & $1,67 \pm 0,08$ & $1,53 \pm 0,10$ \\
\hline $\mathrm{CD} 16,10^{\wedge} 9 / 1$ & $0,08-1,1$ & $0,24 \pm 0,02$ & $0,29 \pm 0,03$ \\
\hline CD16, \% & $12-23$ & $20,08 \pm 0,23$ & $25,00 \pm 0,33 *$ \\
\hline $\mathrm{CD} 22,10^{\wedge} 9 / 1$ & $0,12-1,48$ & $0,58 \pm 0,16$ & $0,49 \pm 0,18$ \\
\hline CD22, \% & $17-31$ & $29,02 \pm 0,23$ & $22,50 \pm 0,25^{*}$ \\
\hline Ig G, g/l & $9-20$ & $10,35 \pm 0,27$ & $10,27 \pm 0,24$ \\
\hline $\operatorname{Ig~M,~g/l~}$ & $0,7-3,7$ & $1,24 \pm 0,19$ & $1,03 \pm 0,12 *$ \\
\hline $\operatorname{Ig} A, g / 1$ & $0,9-5,0$ & $1,77 \pm 0,13$ & $1,96 \pm 0,16$ \\
\hline
\end{tabular}

$*-P<0,05-$ the significance of the difference between the control and experimental groups.

The absolute and relative number of basophils level decrease were committed by 2,0 and 1,8 times in the study group and doesn't exceed a clinical standard. Absolute neutrophil level decrease was committed by $12 \%$. At the same time, the decrease of relative number of monocytes by 1,26 times, respectively, reaches reliable values.

During the research process, the total number of lymphocytes in the control and experimental group are within the clinical norm.

The absolute number of lymphocytes among residents of contaminated areas of Sumy region shows a measure of growth. The relative number of lymphocytes in the experimental group has grown up by 1,19 times relative to the values of the control group over the research period.

Also the absolute number of CD4-lymphocytes (by 13,5\%), absolute and relative level of CD3-lymphocytes (by 16,5 and 3,05\%), and CD8-lymphocytes (by 20,6 and 6,08\%) show a measure of growth in the 
study group and doesn't exceed a clinical standard. But the relative number of CD4-lymphocytes shows a measure of decline by 13,5\% (in comparison with the values of this indicator of residents from conditionally ecologically balanced environment areas of Sumy region) and exceeds the clinical norm.

During the research period the immunoregulatory index of residents from enhanced radioecological monitoring areas shows a slight tendency to decrease. The NK indicators test shows the rise of natural killers (by 17 and $19,7 \%$ ) in peripheral blood against reduction of mononuclear forms.

Absolute and relative number of B-lymphocytes with CD 22 phenotype decrease by 17 and $23,7 \%$ in the researched time period. It was found a decrease of IgG among the residents of enhanced radiological monitoring areas; it was also found that the lowering of IgM related to the control value by 1,2 times. During the research contents of IgA growth by $9,7 \%$.

\section{Interconnection of some indicators of the immune system and thyroid status of individuals from contaminated areas of Sumy region}

In the formation of the regulation of the compensation mechanism for various extreme factors affecting the body, the endocrine system is assigned one of the leading roles. The adequacy and nature of adaptive changes in the body, which ensure the restoration and maintenance of the constancy of the internal environment of the organism as a whole, depend on changes in hormonal secretion ${ }^{43}$.

Indicators of the thyroid system of residents from contaminated and conditionally ecologically balanced environment areas of Sumy region are given in Table 2.

According to the results of medical history among the surveyed no persons with clinical manifestations of thyroid pathology bets.

According to the results of the survey it was established that in the territories of the enhanced radio-ecological control of Sumy region (4th radiation zone; density of soil contamination with isotopes of cesium-137 from 1 to $5 \mathrm{Ki} / \mathrm{km}^{2}$ ) all analyzed parameters are within the clinical norm.

The level of thyrotropic hormone of individuals from contaminated territories shows the rise by 1,19 times. The number of triiodothyronine shows a measure of decrease and the level of thyroxin of residents from enhanced radioecological monitoring areas shows a measure of growth by 1,05 times (for both indicators).

The content of antibodiesto thyroperoxidase also has grown up by $8,6 \%$.

${ }^{43}$ Charmandari E., Tsigos C., Chrousos G. Endocrinology of the stress response. Annual Review of Physiology. 2005. № 67. P. 259-284. DOI: 10.1146/annurev.physiol.67.040403.120816. 
Table 2

Indicators of thyroid status of individuals from contaminated and conditionally ecologically balanced environment territories of Sumy region

\begin{tabular}{|c|c|c|c|}
\hline Indicator & $\begin{array}{c}\text { Clinical } \\
\text { norm }\end{array}$ & $\begin{array}{c}\text { Control group } \\
(\mathbf{M} \pm \mathbf{m}) \mathbf{N}=\mathbf{2 0}\end{array}$ & $\begin{array}{c}\text { Experimental group } \\
\text { (M m m), N=30 }\end{array}$ \\
\hline $\begin{array}{c}\text { Thyrotropic hormone (TTH), } \\
\text { mc units / ml }\end{array}$ & $0,3-4,2$ & $2,51 \pm 0,34$ & $2,99 \pm 0,23$ \\
\hline $\begin{array}{c}\left.\text { Triiodothyronine general ( } \mathrm{T}_{3}\right), \\
\text { pmol / }\end{array}$ & $3,1-6,8$ & $5,06 \pm 0,46$ & $4,82 \pm 0,35$ \\
\hline Thyroxin general ( $\left.\mathrm{T}_{4}\right), \mathrm{pmol} / 1$ & $\begin{array}{c}12,0- \\
22,0\end{array}$ & $13,84 \pm 0,23$ & $14,52 \pm 0,29$ \\
\hline $\begin{array}{c}\text { Antibodies to thyroperoxidase } \\
\text { (ATPO), mc units / ml }\end{array}$ & $0-30$ & $15,96 \pm 0,71$ & $17,46 \pm 0,66$ \\
\hline
\end{tabular}

In healthy individuals, it is difficult to analyze the interrelated changes in endocrine regulation and metabolism, the immune system, since fluctuations within the normal levels of hormones, metabolites, and indicators of systemic immunity are quite significant. However, studies of hormonalmetabolic, hormonal-immunological relationships in individuals who have been exposed to prolonged exposure to factors requiring the mobilization of regulatory systems (including prolonged low-intensity exposure) may indicate the features of their regulation.

Correlation analysis showed that the inhabitants of the territories, contaminated with radionuclides, regardless of thyroid status, there is a positive relationship between:

- the content of TTH and level of CD3-lymphocytes $(r=0,38)$;

- the level of $\mathrm{T}_{3}$ and relative number of neutrophils $(\mathrm{r}=-0,48)$, absolute number of CD3-lymphocytes $(r=0,64)$; content of $\operatorname{IgM}(r=0,93)$;

- the level of $\mathrm{T}_{4}$ and absolute and relative number of CD8-lymphocytes $(r=0,50 ; r=0,48)$, content of $\operatorname{IgM}(r=0,51)$;

- the content of ATPO (Fig. 1.) and level of natural killers $(r=0,49)$.

There is a negative relationship between the level of $\mathrm{T}_{3}$ (Fig. 2.) and relative number of basophils $(\mathrm{r}=-0,85)$, CD3-lymphocytes $(\mathrm{r}=-0,9)$; level of natural killers $(r=-0,38)$; content of $\operatorname{Ig} \mathrm{A}(\mathrm{r}=-0,87)$.

Also there is a negative correlation ofthe level of $\mathrm{T}_{4}$ (Fig. 3.) and relative number of: basophils $(\mathrm{r}=-0,40)$; CD3-lymphocytes ( $\mathrm{r}=-0,57)$; CD4lymphocytes $(r=-0,39)$; contents of $\operatorname{IgG}(r=-0,58)$ and $\operatorname{Ig} A(r=-0,45)$.

Scientific sources testify in recent years, the perception of stress as an extensive systemic response of the organism, which, under certain conditions, can cause impaired function of many physiological systems as expanded considerably ${ }^{44}$.

\footnotetext{
${ }^{44}$ Interconnection of the immune system and the intensity of the oxidative processes under conditions of prolonged exposure to small doses of radiation / V. Sokolenko et al. Regulatory Mechanisms in Biosystems. 2018. № 9 (2). P. 167-176. DOI: $10.15421 / 021825$.
} 


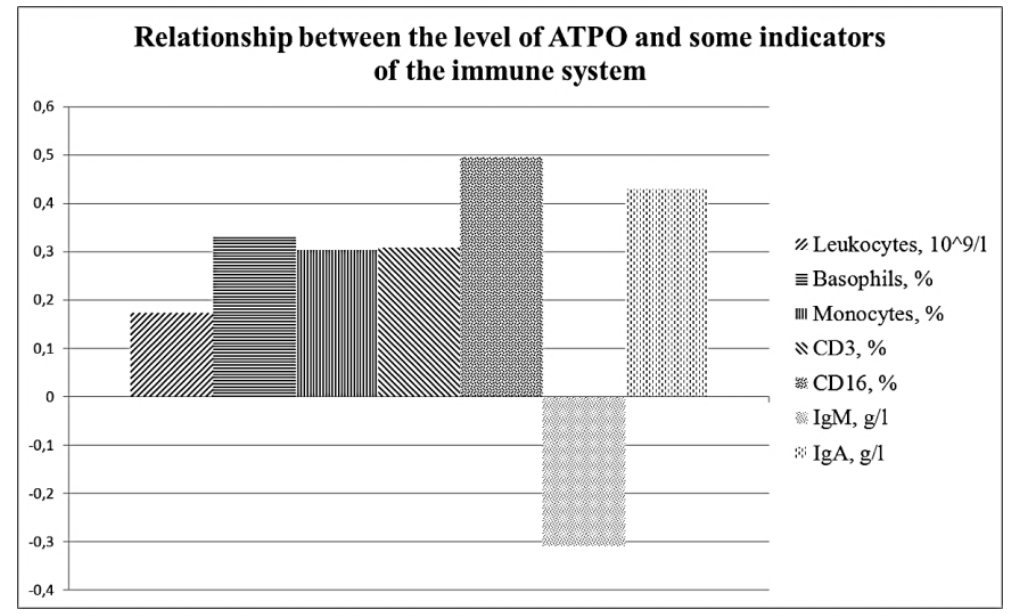

Fig. 1. Interconnection of indicators of the immune system and antibodies to thyroperoxidase of individuals from the territory of enhanced radioecological monitoring of Sumy region

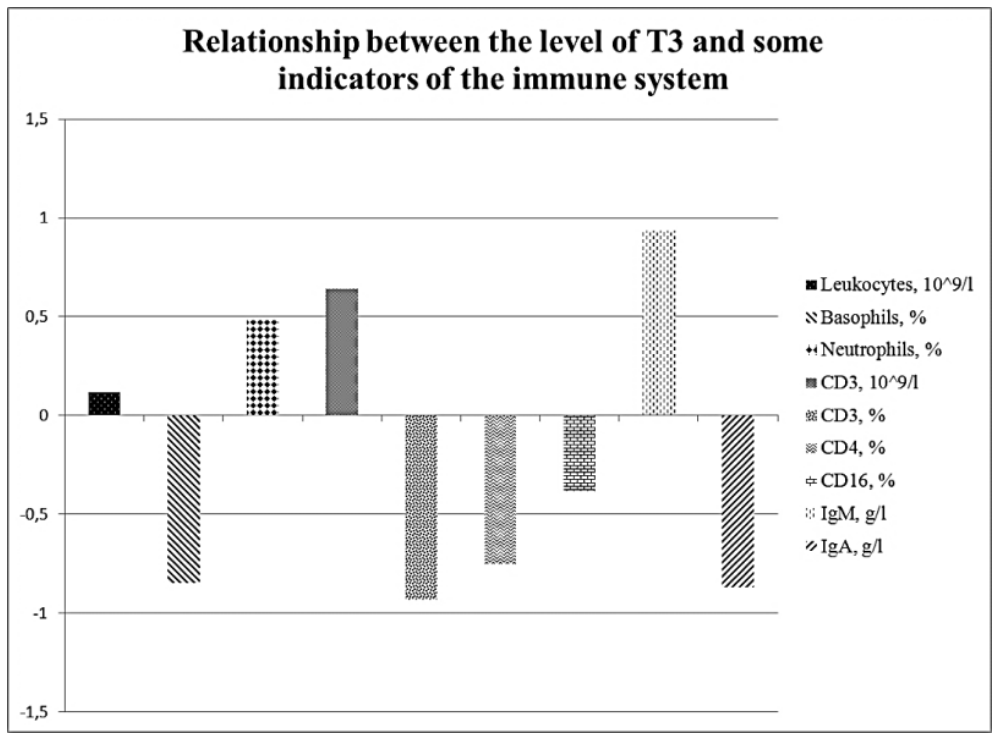

Fig. 2. Interconnection of indicators of the immune system and triiodothyronine of individuals from contaminated areas of Sumy region 


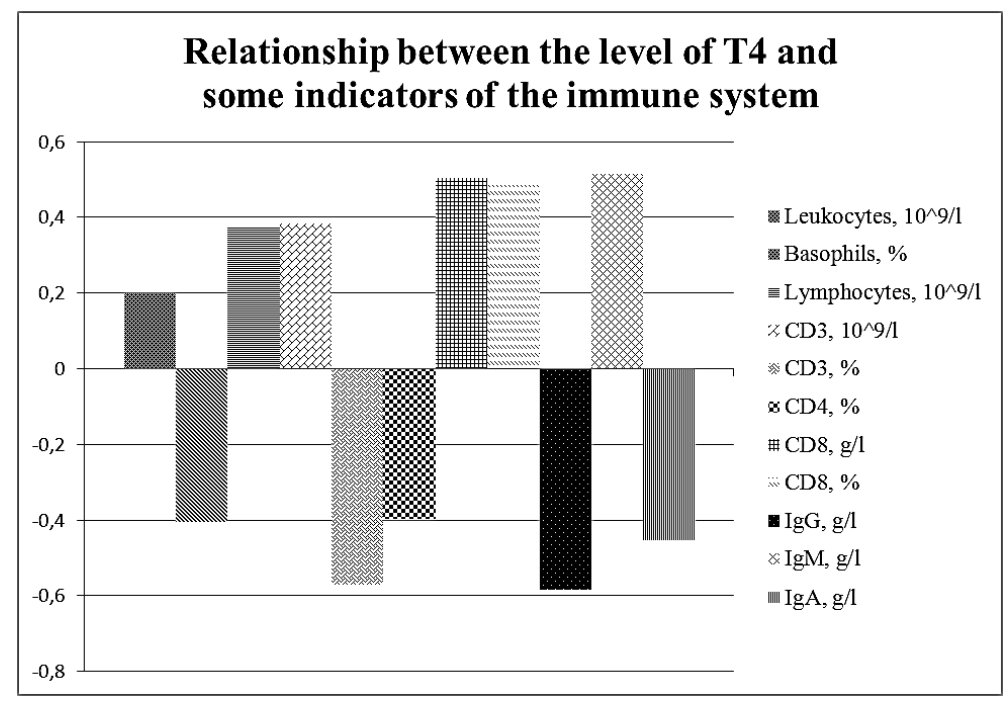

Fig. 3. Interconnection of indicators of the immune system and thyroxin of individuals from radiation-polluted territories of Sumy region

During critical life-threatening illnesses, the increase in cortisol levels was accompanied by a decrease in $\mathrm{T}_{3}$ concentration and an increase in TTH and $\mathrm{T}_{4}$ levels ${ }^{45}$.

In the mechanisms of regulation of homeostasis of the body to provide adaptation in response to stress effects of changes in hormonal secretion, immune regulation is a kind of cascade of closely interrelated reactions. ${ }^{46}$

As is known from scientific sources, autoimmune diseases of the thyroid gland are characterized by a loss of immunological tolerance to their own antigens in genetically predisposed individuals. As a result, the body's own proteins become antigens, for the removal of which the humoral and cellular parts of the immune system are involved. Thus, the chain of events of developing autoimmune inflammation, tissue destruction, stimulation of metabolism, increased growth, or suppression of the mitotic activity

45 Vermes I., Beishuizen A. The neuroendocrinology and immunology of critical illness. Neuroimmune Biology. 2007. № 7. P. 291-317. DOI: 10.1016/S15677443(07)00216-5.

${ }_{46}$ Иванова Г., Горобец JI. Психоиммунноэндокринный статус больных аутоиммунным тиреоидитом (клинико-терапевтические аспекты). Сибирский вестник психиатрии и наркологии. 2010. № 2 (59). С. 57-62. 
of thyrocytes is possible. Certain combinations of these immune reactions lead to the development of various AIG (DTG or AIT) ${ }^{47 ; 48}$.

\section{CONCLUSIONS}

Thus, by investigating the indicators of systemic immunity of individuals in the contaminated territories of the Sumy region (IV-radiation zone), results have been obtained indicating the functional load of cellular link (due to the tendency to increase the number of T-lymphocytes of all subpopulations (CD3, CD4, CD8), as well as the decrease of IRI by $8,4 \%$ in the experimental group.

Besides, the obtained results indicate the functional load of a humoral link of systemic immunity (due to the tendency to decrease absolute and relative number of B-lymphocytes (CD22)). At the same time, there is a certain dynamics of the absolute and relative number of major classes of immune cells, as well as changes in the levels of serum immunoglobulins of classes A and M (may indicate the presence of compensatory mechanisms in response to stress effects).

According to the results of the hormonal examination of individuals from contaminated territories (that coinciding with the scientific data sources) there are the increase in cortisol levels was accompanied by a decrease in $\mathrm{T}_{3}$ concentration and an increase in TTH and $\mathrm{T}_{4}$ levels.

As a result of our study, a certain cohort of the population who underwent an immunological and hormonal examination and received a cutoff value of some of the parameters analyzed was asked to seek qualified medical care by an endocrinologist. As a result, in one male (18 years old) of the experimental group according to ultrasound examination and according to the opinion of a specialist, a case of autoimmune thyroidit is was registered.

In our opinion, the obtained results can be explained by the remoteness of the study area from the epicenter of the nuclear explosion, the insignificant half-life period of cesium isotopes-137 and decay period of iodine-131, as well as the stochasticity of the effects of prolonged effects of low doses of ionizing radiation on the human body.

The obtained results point to the necessity of studying the compensatory mechanisms of the immune system and their potential in providing an effective integrative activity of the human body. At the same time, they indicate the need for immunological surveys for the population in the territories of the intensified radioecological control of our state (and in

47 Состояние метаболизма лимфоцитов крови женщин с аутоиммунным тиреоидитом с различным состоянием функции щитовидной железы / С. Шагарова и др. Медицинская иммунология. 2009. № 11 (4-5). С. 366-367.

48 Особенности метаболизма лимфоцитов крови у женщин с диффузным токсическим зобом в процессе лечения / В. Мацынина и др. Сибирское медицинское обозрение. 2012. № 4. С. 16-20. 
particular, in Sumy region) with the aim of developing and applying immunorehabilitation measures for this category of population, since their organisms are under the prolonged exposure of the influence of the lowintensity ionizing emission. We believe, this research may serve as followings: basis for the formation of risk groups after the monitoring of the health status of the habitants of contaminated areas.

\section{SUMMARY}

The interconnection of some indicators of the immune system and thyroid status of individuals from the territories of the intensified radioecological control of Sumy region (IV-radiation zone; the density of soil contamination with isotopes of cesium-137 3,7 x $10^{4}-18,5 \times$ $104 \mathrm{~Bq} / \mathrm{m} 2$ ) is under investigation.

We observed 50 persons aged between 18-35 and divided them into a control group of volunteers who were from areas unaffected by radiation (20 people) and the main experimental group of people from territories of increased radio-ecological load (IV radiation zone, 30 people).

General methods of studying parameters of immunity and thyroid status were used. Statistical data has been processed. The research was carried out with the written consent of the volunteers in accordance with the bioethical norms and in compliance with the current legislation of Ukraine.

According to the results of the survey it was established that in the territories of the enhanced radio-ecological control of Sumy region (all analyzed parameters are within the clinical norm.

Nevertheless, the obtained results indicate the functional load of the cellular and humoral parts of systemic immune system among the population of radiation-polluted territories of the Sumy region. At the same time, the formation of compensatory mechanisms in response to low-intensity prolonged radiation irradiation is observed.

The individuals tested from territories polluted by radionuclides, has changed dependant on thyroid status, which can become a precondition for the development of stress-induced (including its radiation nature) pathology.

\section{REFERENCES}

1. Тридцять років Чорнобильської катастрофи: радіологічні та медичні наслідки : національна доповідь України / Д. Базика та ін. Київ : ДУ «Національний науковий центр радіаційної медицини Національної академії медичних наук України», 2016. 177 с.

2. Про організацію виконання постанов Верховної Ради Української РСР про порядок введення в дію законів Української РСР «Про правовий режим території, що зазнала радіоактивного забруднення внаслідок Чорнобильської катастрофи» та «Про статус і соціальний захист громадян, які постраждали внаслідок 
чорнобильської катастрофи» : постанова Кабінету Міністрів України від 23 липня 1991 р. № 106.

3. Щорічна доповідь про стан здоров'я населення, санітарноепідемічну ситуацію та результати діяльності системи охорони здоров’я України. 2017 р. / МОЗ України. ДУ «УІСД МОЗ України». Київ : МВЦ «Медінформ», 2018. 458 с.

4. Динаміка змін у поширеності хвороб та захворюваності дитячого населення раїни за окремими класами хвороб після аварії на Чорнобильській АЕС / О. Волосовець та ін. Світ медицини та біології. 2018. № 3 (65). C. 33-42. DOI: 10.26724/2079-8334-2018-3-65-33-42.

5. Ярилин А. Иммунология. Москва : GEOTAR-Media, 2010. 752 с.

6. Risk of thyroid cancer in the Bryansk Oblast of the Russian Federation after the Chernobyl Power Station accident / S. Davis et al. Radiation Research. 2004. № 162 (3). P. 241-248. DOI: 10.1667/rr3233.

7. Eheman C., Garbe P., Tuttle R. Autoimmune thyroid disease associated with environmental thyroidal irradiation. Thyroid. 2003. № 13 (5). P. 453-464. DOI: 10.1089/105072503322021115.

8. Gleeson M. Immune function in sport and exercise. Journal of Applied Physiology. 2007. № 103 (2). P. 693-699. DOI: 10.1152/japplphysiol.00008.2007.

9. Individual differences in cellular immune response to stress / S. Manuck et al. Psychological Science. 1991. № 2 (2). P. 111-115. DOI: 10.1111/j.1467-9280.1991.tb00110.x.

10. Effect of ionizing radiation on development process of T-cell population lymphocytes in Chernobyl children / M. Sheikh Sajjadieh et al. Iranian Journal of Radiation Research. 2009. № 7 (3). P. 127-133. URL: Magiran.com/p731386.

11. The effect of ionizing radiation on the homeostasis and functional integrity of murine splenic regulatory T cells / A. Balogh et al. Inflammation Research. 2013. № 62 (2). P. 201-212. DOI: 10.1007/s00011-012-0567-y.

12. Kusunoki Y., Hayashi T. Long-lasting alterations of the immune system by ionizing radiation exposure: Implications for disease development among atomic bomb survivors. International Journal of Radiation Biology. 2008. № 84 (1). P. 1-14. DOI: 10.1080/09553000701616106.

13. T-cell immunosenescence and inflammatory response in atomic bomb survivors / Y. Kusunoki et al. Radiation Research. 2010. № 174 (6b). P. 870-876. DOI: 10.1667/RR1847.1.

14. High mobility group box-1 promotes the proliferation and migration of hepatic stellate cells via TLR4-dependent signal pathways of PI3K /Akt and JNK / F. Wang et al. PloS One. 2013. № 8 (5). P. 643-673. DOI: 10.1371/journal.pone.0064373.

15. Duffner P. Long-term effects of radiation therapy on cognitive and endocrine function in children with leukemia and brain tumors. 
The Neurologist. 2004. № $10 \quad$ (6). $\quad$ P. 293-310. $\quad$ DOI: 10.1097/01.nrl.0000144287.35993.96.

16. Effects of long-term low-level radiation exposure after the Chernobyl catastrophe on immunoglobulins in children residing in contaminated areas: prospective and cross-sectional studies / D. McMahon et al. Environmental Health. 2014. № 13 (1). P. 36-50. DOI: 10.1186/1476-069X-13-36.

17. Segerstrom S., Miller G. Psychological stress and the human immune system: A meta-analytic study of 30 years of inquiry. Psychological Bulletin. 2004. № 130 (4). P. 601. DOI: 10.1037/0033-2909.130.4.601.

18. Viru A., Viru M. Cortisol-essential adaptation hormone in exercise. International Journal of Sports Medicine. 2004. № 25 (6). P. 461-464. DOI: 10.1055/s-2004-821068.

19. Psychophysiological stress in tennis players during the first single match of a tournament / E. Filaire et al. Psychoneuro-endocrinology. 2009. № 34 (1). P. 150-157. DOI: 10.1016/j.psyneuen.2008.08.022.

20. John D., Boice Jr. Chapter 3 - From Chernobyl to Fukushima and Beyond - A focus on thyroid cancer. Thyroid cancer and nuclear accidents. Long-term aftereffects of Chernobyl and Fukushima. 2017. P. 21-32.

21. Non-cancer atherosclerotic effects associated with environmental and therapeutic radiation doses : The Chernobyl thyroid cancer children study / R. Bruno et al. International Journal of Cardiology. 2013. № 168 (4). P. 4255-4257. DOI: 10.1016/j.ijcard.2013.04.161.

22. Особливості ліпідного спектру крові у нащадків ліквідаторів аварії на ЧАЕС / М. Коренєв та ін. Современная педиатрия. 2009. № 3. C. 56-58.

23. Рожко А. Чернобыльская катастрофа: медико-биологические закономерности формирования и прогнозирование тиреоидной патологии у населения. Міжнародний ендокринологічний журнал. 2011. № 4. C. 84-93.

24. Low dose irradiation of thyroid cells reveals a unique transcriptomic and epigenetic signature in RET/PTC-positive cells / K. Abou-El-Ardat et al. Mutation Research / Fundamental and Molecular Mechanisms of Mutagenesis. 2012. № 731 (1). P. 27-40. DOI: 10.1016/j.mrfmmm.2011.10.006.

25. Fushiki S. Radiation hazards in children-lessons from Chernobyl, Three Mile Island and Fukushima. Brain and Development. 2013. № 35 (3). P. 220-227. DOI: 10.1016/j.braindev.2012.09.004.

26. Radiation and risk of thyroid cancer: Fukushima and Chernobyl / N. Takamura et al. The Lancet Diabetes and Endocrinology. 2016. № 4 (8). P. 647. DOI: 10.1016/S2213-8587(16)30112-7.

27. Contis G., Foley Jr. Depression, suicide ideation, and thyroid tumors among Ukrainian adolescents exposed as children to Chernobyl radiation. Journal of clinical medicine research. 2015. № 7 (5). P. 332-338. DOI: $10.14740 /$ jocmr2018w. 
28. Соколенко В., Соколенко С. Активність радіонуклідів і реалізація функцій імунної системи у мешканців радіаційно забруднених територій. Вісник Дніпропетровського університету. Серія «Біологія, медицина». 2015. № 6 (2). С. 93-96. $10.15421 / 021517$.

29. Соколенко В., Соколенко С. Вплив факторів стресової природи на показники імунної системи. Вісник Черкаського університету. Біологічні науки. 2015. № 19 (352). С. 110-114.

30. Соколенко В. Показники клітинного імунітету в осіб з певними особливостями тиреоїдного статусу за умов хронічного опромінення в малих дозах. Вісник проблем біологї̈ $і$ медищини. 2016. № 1 (126). C. 403-409.

31. Sokolenko V., Sokolenko S. The interaction between lipid exchange and thyroid status in the conditions of prolonged influence of small doses of radiation. Regulatory Mechanisms in Biosystems. 2017. № 8 (2). P. 231-238. DOI: $10.15421 / 021736$.

32. Interconnection of the immune system and the intensity of the oxidative processes under conditions of prolonged exposure to small doses of radiation / V. Sokolenko et al. Regulatory Mechanisms in Biosystems. 2018. № 9 (2). P. 167-176. DOI: 10.15421/021825.

33. Білокур Д. Показники неспецифічного антиінфекційного захисту у осіб з територій посиленого радіоекологічного контролю Сумської області. Вісник Східноєвропейського наиіонального університету імені Лесі Украӥнки. Серія «Біологічні науки». 2018. № 4 (377). С. 86-91.

34. Білокур Д., Львов О., Шейко В. Динаміка показників гуморального імунітету у осіб з контамінованих територій Сумської області. Вісник проблем біології і медищини. 2018. № 3 (145). С. 59-62. DOI: 10.29254/2077-4214-2018-3-1-145-59-62.

35. Білокур Д. Динаміка показників клітинного імунітету в осіб 3 контамінованих територій Сумської області. Вісник проблем біології $i$ медищини. 2018. Вип. 4. Т. 2 (147). С. 113-116. DOI: 10.29254/20774214-2018-4-2-147.

36. Higher free triiodothyronine is associated with non-alcoholic fatty liver disease in euthyroid subjects : The lifelines cohort study / E. van den Berg et al. Metabolism. 2017. № 67. P. 62-71. DOI: 10.1016/j.metabol.2016.11.002.

37. Hidaka Y. Chronic thyroiditis (Hashimoto's disease). Nippon Rinsho. 2005. № 63 (10). P. 111-115.

38. Establishment of clinical diagnosis model of Graves' disease and Hashimoto's thyroiditis / Z. Cui et al. J Transl. Med. 2019. № 17 (1). P. 11. DOI: 10.1186/s12967-018-1765-3.

39. Меньшиков В. Лабораторные методы исследования в клинике Москва : Медицина, 1987. 
40. Додатковий протокол до Конвенції про права людини та біомедицину в галузі біомедичних досліджень (ETS № 195) / Верховна Рада України.

41. Larzelere M., Jones G. Stress and health. Primary Care. Clinics in Office Practice. 2008. № 35 (4). P. 839-856. DOI: 10.1016/j.pop.2008.07.011.

42. Кубасов Р. Гормональные изменения в ответ на экстремальные факторы внешней среды. Вестник Российской академии медицинских наук. 2014. № 69 (9-10). С. 102-109.

43. Charmandari E., Tsigos C., Chrousos G. Endocrinology of the stress response. Annual Review Physiology. 2005. № 67. P. 259-284. DOI: 10.1146/annurev.physiol.67.040403.120816.

44. Vermes I., Beishuizen A. The neuroendocrinology and immunology of critical illness. Neuroimmune Biology. 2007. 7. P. 291-317. DOI: 10.1016/S1567-7443(07)00216-5.

45. Иванова Г., Горобец JI. Н. Психоиммунноэндокринный статус больных аутоиммунным тиреоидитом (клинико-терапевтические аспекты). Сибирский вестник психиатрии и наркологии. 2010. № 2 (59). C. $57-62$.

46. Состояние метаболизма лимфоцитов крови женщин с аутоиммунным тиреоидитом с различным состоянием функции щитовидной железы / С. Шагарова. Медицинская иммунология. 2009. № 11 (4-5). С. 366-367.

47. Особенности метаболизма лимфоцитов крови у женщин с диффузным токсическим зобом в процессе лечения / В. Мацынина. Сибирское медииинское обозрение. 2012. № 4. С. 16-20.

\section{Information about authors:}

Bilokur D. O.,

Postgraduate Student of the Department of Human and Animals Biology Sumy State Pedagogical University named after A. S. Makarenko 87, Romenska str., Sumy, 40002, Ukraine

Sheiko V. H., Doctor of Biological Sciences, Professor at the Department of Human and Animals Biology Sumy State Pedagogical University named after A. S. Makarenko 87, Romenska str., Sumy, 40002, Ukraine 